\title{
Use Of The Thermo-Hygro Buttons in Tracking The Influence Of Humidity And Temperature On The Deterioration Of The Building Stones Of The Mausoleum Of Imedghassen Batna In Algeria
}

\author{
M. Hamiane ${ }^{1, a}$, C.Assafsaf ${ }^{2}$ \\ ${ }^{1}$ University M'Hamed Bougara, (UR-MPE) .Independence Avenue, 35000 Boumerdes, Algeria
}

\begin{abstract}
The tomb of Imedghassen is a pre-Roman royal mausoleum located at $420 \mathrm{Km}$ from Algiers. It is dated back to the $3^{\text {rd }}$ century B.C. It is built with building stones. The semi-arid continental climate, of the chosen location, is characterized by strong temperature fluctuations and high evaporation. These two factors have a great influence on the building stones' state of degradation. The infiltration of water in this very rainy region, related to time , had a serious impact on the monument. To get accurate results about the influence of temperature and humidity, we had controlled the microclimate of the mausoleum using PC Thermo track; thermo-hygro buttons. It allowed us to accurately track the values of the average and higher temperature and humidity, and also the dew point. The results clearly show the relationship between these factors and the origin of the building stone deterioration.
\end{abstract}

Keywords: Degradation, Mausoleum Imedghassen, Temperature, Humidity, Thermo Hygro-buttons

\section{Introduction}

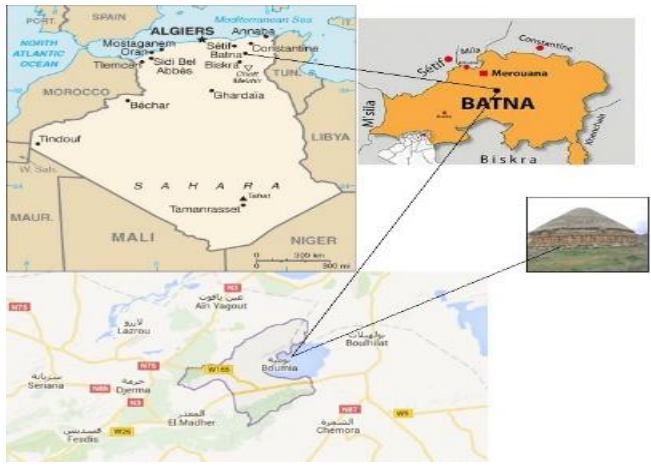

Figure 1. Geographic location.

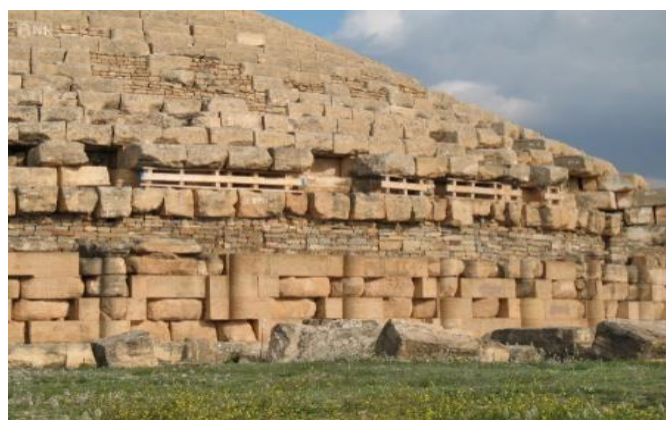

Figure 2. Stone blocks of the Mausoleum
Imedghassen Mausoleum is a monument listed as a national heritage. It is located in the wilaya of Batna, at the altitude of 914 meters (figure 1). The building measures $18.35 \mathrm{~m}$ in hight and $58.86 \mathrm{~m}$ in base diameter. The cylindrical base is embellished with decorative columns. The mausoleum is dated back to the $3^{\text {rd }}$ or $4^{\text {th }}$ century BC. It is entirely built from huge blocks of stones together without mortar, joined by lead studs, and small stones (Figure 2).

The monument is in an alarming state of degradation. Several factors are responsible for this deterioration. However we are interested in our article for damages caused by the effect of temperature and humidity.

The semi-arid continental climate of the chosen location, characterized by strong temperature fluctuations and high evaporation, has a great influence on the conservation state of the mausoleum. The infiltration of water in this very rainy region very related to time , had a severe impact on the monument .To get accurate results about the influence of temperature and humidity, we had controlled the mausoleum microclimate using a PC Thermotrack thermo-hygro buttons logger . It allowed us to accurately track the values of the average and higher temperature, humidity and also the dew point. The results clearly show the relationship between these factors and the origin of the stone deterioration.

\footnotetext{
${ }^{1}$ hamiane@univ-boumerdes.dz
} 


\section{Mausoleum Damage Factors}

Among the most significant degradation factors that appear clearly on the mausoleum, are: Plants, lichens, algae, and cracks, color change of stones, Crystallization of salts, corrosion of stones, rising damp (capillary), water infiltration, loss of stone mass and rubble. However the rain, change in humidity and temperature factors have a marked influence on the degradation of the monument. Figures (3 to 6) show these different types of degradation.

\section{Plants}

We note the growth of plants of all kinds, in particular between the stones. These plants are abundant in winter because of the availability of water. Over time, these plants have made space between stones, and consequently, the demolition of the walls of the mausoleum as a result.

\section{Microscopic plants}

They are represented by algae and lichens, deployed on many stones of the building. They appear as spots or crust, green, yellow or white, depending on lichens. These plants develop on the outer surface of the stones; this alters the stones and influences the aesthetic side of mausoleum. The density of these algae is particularly enhanced in the spaces between the stones, where there are shade, moisture and water.

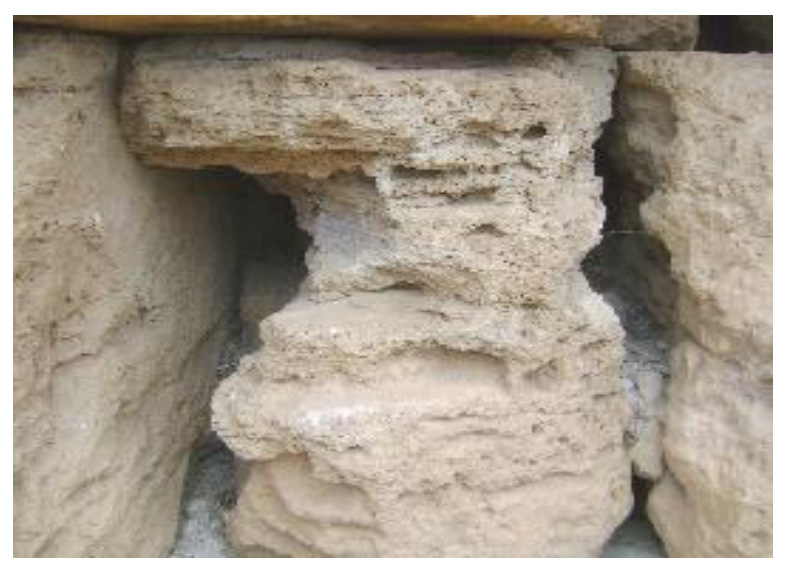

Figure 3. Plant growth

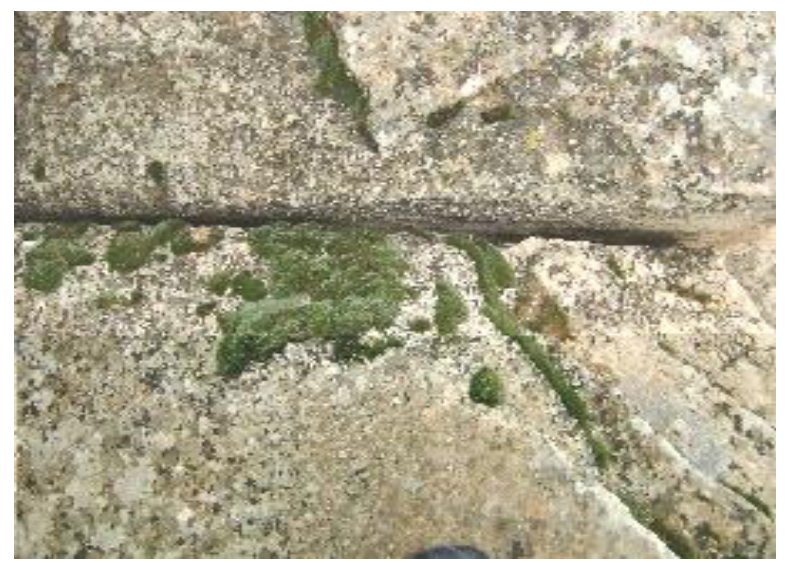

Figure 4. Lichens growth

\section{Cracks in the rocks}

Some stones show visible cracks. We see wide and narrow cracks, vertical and horizontal. The wide variations in temperature and moisture content may be the cause of these cracks. The mechanical pressure of new stones substitued during the restoration, and the presence of plants can also be the cause of these fractures.

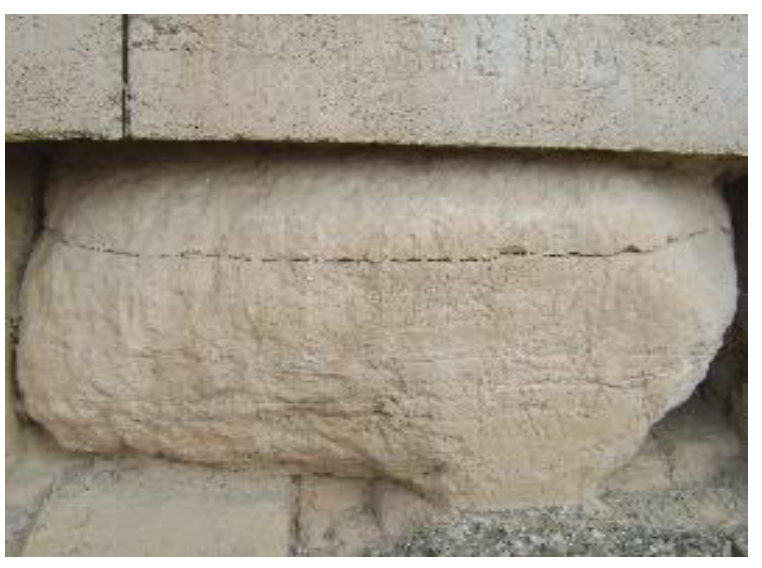

Figure 5. Horizontal cracks

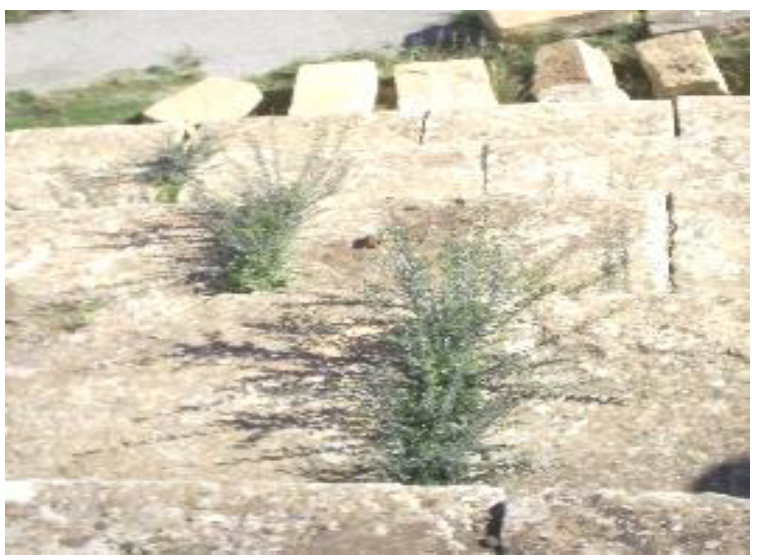

Figure 6. Corrosion stones

\section{Corrosion of stones}

The mechanical action combined with rain, wind, sand and time has changed the shape of the stones, decreased their size and a mass loss. The surface corroded stone comes off easily.

\section{Efflorescence of salts}

The bottom capillary moisture of the wall of the soil, the dissolution of the salts by water from rain and the evaporation of water at high temperature of the surfaces of the stones, are the main cause of salt crystallization. Mausoleum Imedghassen shows very well this phenomenon. White layers are observed on the first sitting of the monument. 


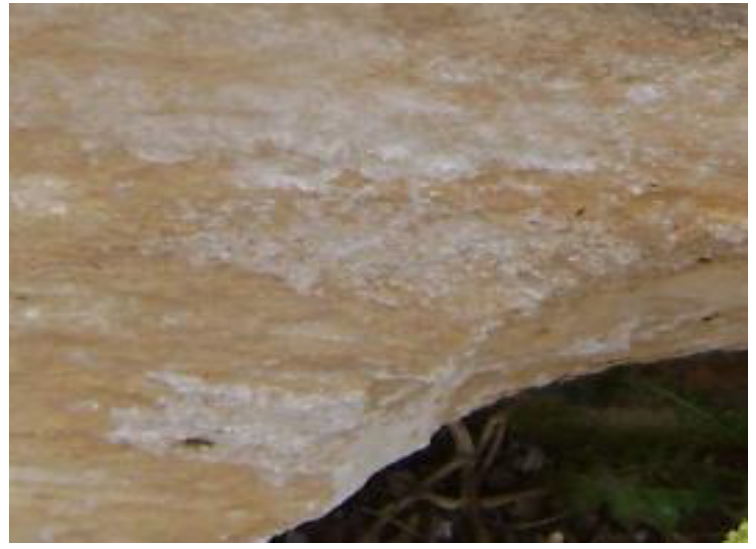

Figure 7. Efflorescence salts

\section{EXPERIMENTATION}

\subsection{Thermal shock}

The samples are subjected to high temperature (from $60^{\circ} \mathrm{C}$ to $250^{\circ} \mathrm{C}$ ). After 15 minutes in an oven, the samples were placed in cold water at $5^{\circ} \mathrm{C}$. Observations show no change for all samples subjected to the temperatures $\left(60^{\circ} \mathrm{C}\right.$ to $\left.100^{\circ} \mathrm{C}\right)$. For the temperature range $\left(120^{\circ} \mathrm{C}\right.$ to $180^{\circ} \mathrm{C}$ ), all samples show a slight mass loss. For the temperature 220, slight mass loss for some samples and loss of small pieces for others. The samples subjected to the temperature of $250^{\circ} \mathrm{C}$, have become friable, with loss of mass and color change.

\subsection{Effect of freeze / thaw}

After drying the samples in a drying oven until a constant mass, the samples were immerged for $48 \mathrm{~h}$ in water with a temperature $\left(15 \pm 5^{\circ} \mathrm{C}\right)$. The samples were then placed in a refrigerating machine with a temperature $\left(-15 \pm 5^{\circ} \mathrm{C}\right)$ .After a period of 4 hours, the samples were put back into water at $\left(15 \pm 5^{\circ} \mathrm{C}\right)$ for $4 \mathrm{~h}$. The experience is repeated five times $(5 \mathrm{X})$.The samples are then left in the open air for $24 \mathrm{H}$. They are weighed after drying in an oven at a temperature of $\left(105 \pm 5^{\circ} \mathrm{C}\right)$. The results showed that the mass loss $(\%)$, for the three samples are : $(0.24 ; 0.26$ and $0.30)$.

\subsection{Influence of moisture on the samples}

The solutions are prepared in the laboratory to create relative moisture of $45 \%$ and $95 \%$. The solutions were placed in desiccators, with perforated partitions, so that the samples are not in contact with the solution. After drying in an oven until a constant weight, they are put into a $45 \%$ environment and $95 \%$ relative moisture. The masses are weighed after different time ( $t 1$, $t 2$, t3 .................tn) with tn equal to 30 days. The results are shown by the graphs of Figure 8 .

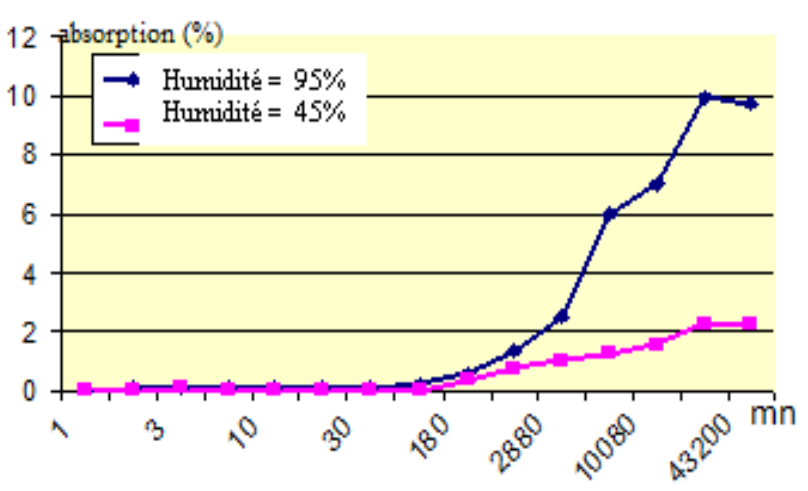

Figure 8. Influence of the $\mathrm{H}(45 \%$ and $95 \%)$ on the samples for 30 days

\subsection{Monitoring of temperature and relative humidity in the site}

This experience is to program the thermo-hygro buttons and set them in representative areas of imedghassen Mausoleum. The experiment was performed during the winter and summer seasons. The choice fell on facade walls whose conservation status is different.

The thermo hygro button is the smallest temperature and humidity logger in the world.

Ideal for monitoring the temperature and humidity, but also for stability testing for the conservation of artifact...Small, rugged, it fits everywhere and supports shock, dust. All records are archived and stored in its protected memory.

Battery life span: up to 10 years.

- Records date and time

- Programmable low and high alarm threshold with temporization parameters

- Free memory for traceability data storage

The Thermo-Hygro Button designation and precision are:

Temperature measurement range $-20 /+85^{\circ} \mathrm{C}$

Temperature accuracy $\pm 0.5^{\circ} \mathrm{C}$

Measuring range humidity $0 /+100 \%$

$\mathrm{RH}$ Accuracy $\pm 5 \%$

Resolution 0.1 or $0.5^{\circ} \mathrm{C}$

Number of measurements 4096 or 8192

Measuring rate $1 \mathrm{sec}$ to $273 \mathrm{~h}$

Starting if possible alarm Yes

\subsubsection{Placement of the first thermo-hygro-button}

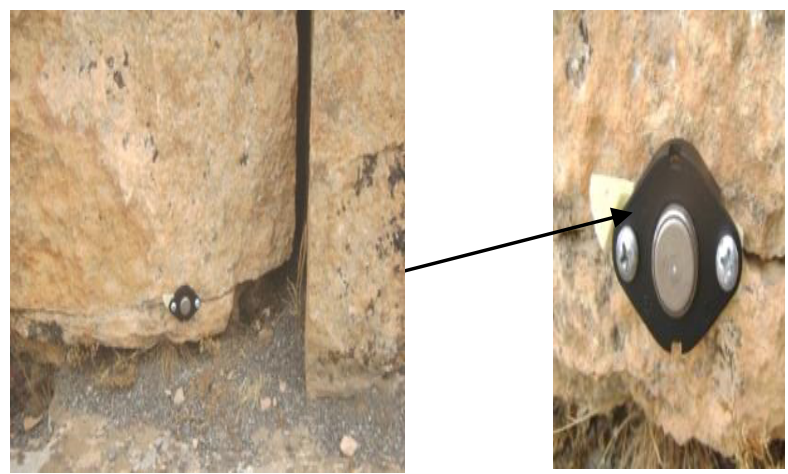

Figure 9. Placement of the thermo-hygro-button 
The Thermo-hygro button was placed in the north facade wall, from January 13 to February 12 . Figure 9, showing the location of thermo hygro button in the wall and in Figure. 10, showing the registration of the temperature variation, humidity and dew point during this period. The summary of the recorded mean values are:

$\mathrm{H}(\%) \max =100 ; \mathrm{H}(\%) \min =41.8 ; \mathrm{H}(\%)$ Average $=85.51$ $\mathrm{T}\left({ }^{\circ} \mathrm{C}\right) \max =27.9 ; \mathrm{T}\left({ }^{\circ} \mathrm{C}\right) \min =0.4 ; \mathrm{T}\left({ }^{\circ} \mathrm{C}\right)$ Average $=7.88$

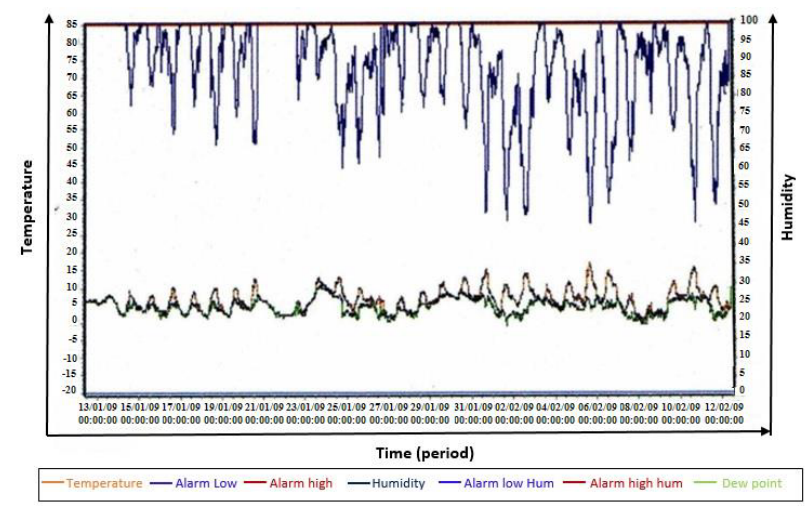

Figure 10. Recording result of $\mathrm{H}(\%)$ and $\mathrm{T}^{\circ} \mathrm{C}$, the winter period, North façade

\subsubsection{Placement of the second thermo-hygro button}

The Thermo-hygro button was placed in the East facade of the wall, from January 13 to February 12. The summary of the recorded mean values are:

$\mathrm{H}(\%) \max =100 ; \mathrm{H}(\%) \min =17.16 ; \mathrm{H}(\%)$ Average $=76.49$

$\mathrm{T}\left({ }^{\circ} \mathrm{C}\right) \max =37.7 ; \mathrm{T}\left({ }^{\circ} \mathrm{C}\right) \min =0.0 ; \mathrm{T}\left({ }^{\circ} \mathrm{C}\right)$ Average $=11.17$

\subsubsection{Placement of the third-thermo-hygro button}

The thermo-hygro button was placed in the west facade wall, of 27 June to 9 August. The summary of the recorded mean values are:

$\mathrm{H}(\%) \max =100 ; \mathrm{H}(\%) \min =53 ; \mathrm{H}(\%)$ Average $=28.6$; $\mathrm{T}\left({ }^{\circ} \mathrm{C}\right) \max =61,4 ; \mathrm{T}\left({ }^{\circ} \mathrm{C}\right) \min =15.8 ; \mathrm{T}\left({ }^{\circ} \mathrm{C}\right)$ Average $=$ 31.9

\section{Interpretation}

\subsection{Interpretation of physical results (thermal shock and freeze / thaw)}

Samples of stone buildings that are limestone, with an open porosity $35.15 \%$ type, have shown the influence of temperature in the analysis of thermal shock, with slight loss of mass from $120^{\circ} \mathrm{C}$ until color change and loss of small pieces to $250^{\circ} \mathrm{C}$. Samples submitted to the effect of freeze / thaw, show after five cycles, a mass loss of $0.30 \%$.This explains well the effect of changes in temperature and humidity on cracking building stones of mausoleum.

\subsection{Interpretation of the results of the influence of humidity $(45 \%$ and $95 \%)$}

The samples, subjected to a $45 \%$ environment and $95 \%$ relative humidity for a period of 30 days, showed that the limestone-type samples, with significant open porosity, absorb moisture from the surrounding .This absorption increases with increase of the amount of moisture, increased porosity and the exposure time of the samples in that environment. This clearly shows the effect of changes in humidity, rain and rising damp on the alteration of building stones. The different types of alterations observed in the site (micro organisms, lichens, efflorescence, weight loss, etc.), are accelerated by the presence of moisture.

\subsection{Interpretation of humidity and temperature monitoring results in the site}

Three thermo-hygro buttons after programming were placed respectively:

- North facade (less exposed to wind and temperate) and best preserved

- Eastern Front (more exposed to wind and temperate), less conserved

West facade (average state of preservation)

\section{Winter period:}

After 30 recording days (from January 13 to February 12), we remove the thermo-hygro buttons from the mausoleum walls and reading them, via the PC software Thermo track. The results are shown in the Figure 10 (thermo-hygro1).It shows the variations in temperature and humidity during attempts (30) days .The values do not show large variations between day and night, against the (thermo_hygro2), that shows that the gap is very important between the values of day and night, with large amplitudes during the 30 days of recording The results clearly show the difference in temperature and humidity between the two facades (North and East). This clearly explains the influence of climatic parameters on the state of degradation of the east façade against the north wall.

\section{Summer Period}

After 42 days of recording (from 27 June to 9 August) .The thermo-hygro buttons after reading the results, clearly show the difference of temperature and humidity values between the winter and the summer period with a temperature difference min $\left(9.8 \pm 0.5^{\circ} \mathrm{C}\right)$ and $\max (15.8$ $\pm 0.5^{\circ} \mathrm{C}$ ) and a standard deviation for the Humidity of $\max (11.86 \pm 0.1 \%)$. These large variations in Humidity and temperature may be the main cause of some cracks observed on the mausoleum stones.

\section{Conclusion}

Building stones of the mausoleum Imadghassen are in advanced state of deterioration. The parameters responsible for that status are many, and they affect each 
other. We denote particular factors of humidity and temperature. The large magnitude of the variation of humidity and temperature between day and night and between winter and summer, registered in the site, confirm the relationship between these parameters and the degradation state of the monument. The samples subjected to the influence of humidity (45\% and 95\%) showed that the amount of the absorption increases with the amount of humidity, open porosity and the time of exposure of the samples to this environment. The mass loss recorded in the test of thermal shock and freezing / thawing, confirm the relationship between these factors and the conservation status of mausoleum.

\section{References}

1. Adam .J.P, Boussoutrot .A. " restauration architecturale et préservation des sites archéologiques ", dans : conservation restauration en archéologie, France , 1990.

2. Adam .J.P, La construction romaine : matériaux et techniques, troisième édition, édition A et J.Picard, Paris, 1995.

3. Blas J.M, Sintes .C, sites et monuments antiques d'Algérie, France, 2003.

4. C.Assafsaf, M.Hamiane. Approche d'étude technique de l'état de conservation du mausolée d'Imadghasen. Mémoire de Magistère, Algérie. (2010).

5. Camps. G, " nouvelles observation sur l'architecture et l'âge du Medracen mausolée royal de Numidie", dans : compte rendus de l'académie des inscriptions, 1973.

6. Gsell. S, histoire ancien de l'Afrique du nord, tome VI, 1972.

7. ICOMOS," Glossaire illustré sur les formes d'altération de la pierre ", France, 2008, dans : www.intrnational.icomos.org

8. M.Hamiane, C.Assafsaf, M.Bouteflika, W.Zekagh, Etat de conservation et lutte contre les graffitis du Mausolée d'Imedghassen de Batna en Algérie. Conférence internationale. Conservation de la pierre. Paris (2011).

9. M.Hamiane, C.Assafsaf, M.Bouteflika, W.Zekagh, M.Saidi, L'état de conservation du Mausolée d'Imedghassen de Batna en Algérie.1er Colloque sur le Patrimoine Maure (Amazigh) du Maroque Antique. (2013).

10. Shaw .T, Voyage dans la régence d'Alger au XVIII ${ }^{\mathrm{e}}$ siècle, traduit par : Carthy (E.M), grande Alger livres éditions, Alger, 2007.

11. Torraca .G, matériaux de construction poreux, iccrom, Italie, 1986. 